University of South Carolina

Scholar Commons

8-1987

\title{
The Impact of the Supreme Court on Trends in Economic Policy Making in the United States Courts of Appeals
}

Donald R. Songer

University of South Carolina - Columbia, dsonger@sc.edu

Follow this and additional works at: https://scholarcommons.sc.edu/poli_facpub

Part of the Law Commons, and the Political Science Commons

Publication Info

Published in Journal of Politics, Volume 49, Issue 3, 1987, pages 830-841.

http://www.journalofpolitics.org/

(C) 1987 by Cambridge University Press for the Southern Political Science Association

This Article is brought to you by the Political Science, Department of at Scholar Commons. It has been accepted for inclusion in Faculty Publications by an authorized administrator of Scholar Commons. For more information, please contact digres@mailbox.sc.edu. 


\title{
The Impact of the Supreme Court on Trends in Economic Policy Making in the United States Courts of Appeals
}

\author{
Donald R. Songer \\ University of South Carolina
}

Previous impact research has primarily investigated controversial civil liberties decisions. The present study examines the response of the United States Courts of Appeals to changes in the labor and antitrust policies announced by the Supreme Court between 1950 and 1977. Significant impact was discovered. In each policy area, the decisional trends of the courts of appeals underwent a significant change after each of two policy shifts on the Supreme Court. Changes in the decisional trends of the courts of appeal were in the predicted direction even after controls were introduced for judges' party and holdover effects.

\section{I}

a recent assessment of research to date in judicial impact, Johnson and Canon (1984) suggest that too much attention has been given to following up a very few dramatic Supreme Court decisions. They argue that "in focusing on the extraordinary, we have forgotten the ordinary. We believe a complete understanding of the process in the implementation and impact of judicial policies must also include data about cases less heralded but nonetheless still important" (1984, p. ix). This concentration on the dramatic has meant that most empirical research dealt with the impact of a highly biased sample of Supreme Court policies: mainly controversial civil liberties decisions-especially those of the Warren Court (Baum, 1978). Wasby's (1970) admonition more than a decade ago that there was a need for more analysis of the impact of the Court on economic policy has gone virtually unheeded. Even though the Supreme Court devotes considerable energy to economic policy, the impact of its work in this field has been virtually ignored (Baum, 1977, p. 132).

A potential danger of such a limited research focus is that the overall impact of the Supreme Court may be seriously underestimated. Controversial policies may be precisely those in which the impact of the Supreme Court on lower courts is at its minimum (Baum, 1978, p. 210; Johnson and Canon, 1984, pp. 58-60). Shifting the focus of analysis to the Court's economic policy-making may contribute to a more balanced assessment of its overall impact on lower courts. While substantively important, the Court's economic decisions have rarely generated the

-The author wishes to express his appreciation for the Project ' 87 grant which partially funded the research reported in this paper. 
degree of passion and controversy that have followed some of its decisions on race relations and criminal procedure. Consequently, their impact may be greater. For example, Wasby $(1970$, p. 103) suggests that "an area of law in which it is often speculated that considerable impact has occurred is antitrust, but much of what has been written is speculation; we are without studies to match the speculation."

The present study attempts to redress partially the balance in impact studies with an analysis of the impact of the Supreme Court on economic policy-making in the United States Courts of Appeals. The focus is on the labor and antitrust decisions of the courts of appeals from 1950 through 1977.

Much of the literature on the impact of the Supreme Court on lower courts has dealt with their compliance with specific decisions of the Supreme Court. Although such studies have illuminated some significant problems, a compliance focus inevitably misses much of the dynamics of the relationships between courts in our federal system. Lower courts may fail to support the basic policy of the Supreme Court without being overtly noncompliant with any specific decision (see Wasby, 1970, ch. 2 for a discussion of the problem). As Beatty $(1972$, p. 261) puts it, there are many ways for courts to "avoid, mitigate or nullify the ruling or advice of the Court" which stop short of overt defiance or noncompliance. Therefore, to gain a more complete understanding of the significance of the constitutional rules announced by the Supreme Court, a broader concept of impact needs to be used. A further problem with the use of a compliance model is that the focus on a few selected decisions is too narrow to gauge the impact of the Court on a given policy area. Canon (1973) maintains that the central significance of the Court for constitutional development is not the specific decisions it makes but the broad policies it fashions from a series of decisions. Baum (1977) expands on this idea to argue that much of an appellate court's policy leadership is exercised through the establishment of decisional trends that signal its inclination without creating a complete set of explicit rules of law. He suggests that there is a great need for research designed to measure the response of lower courts to these more general "decisional trends" of appellate courts in a wide variety of policy areas.

The analysis reported below examines the policy leadership exerted by the Supreme Court on the labor and antitrust decisional trends in the United States Courts of Appeals. It is generally believed that judicial decisions which lack clarity because of their complexity are less likely to have positive impact on the courts below (Johnson and Canon, 1984, p. 49). Since labor and antitrust policies are by nature complex (Johnson and Canon, 1984, p. 32), it might be speculated that the impact of the Supreme Court in these policy areas will be relatively modest. However, if the 
direction of Supreme Court policy is substantially altered through a series of decisions, the overall change in the decisional trends of the Court should be quite clear even if the details of some specific decisions remain somewhat ambiguous. Therefore, the capability of the Supreme Court to influence the decisional trends of lower courts should not be hampered by the complexity of its decisions. Since labor and antitrust decisions of the Supreme Court have not generally stimulated widespread intense controversy and since there are no other obvious environmental pressures on the lower courts to disregard Supreme Court policy leadership, it is expected that the Court will have a substantial impact on the labor and antitrust decisions of the courts of appeals. Specifically, it is hypothesized that after any statistically significant change in the percentage of liberal decisions announced by the Supreme Court in either of the policy areas under investigation, there will be a statistically significant change in the same direction in the percentage of liberal decisions announced by the United States Courts of Appeals.

\section{Data ANd METhods}

The initial analysis of the impact of the Supreme Court was based on all of the labor and antitrust decisions of both the Supreme Court and the United States Courts of Appeals that were published with full opinions (including per curiam opinions) from 1950 through 1977.1 The sample of antitrust decisions of the courts of appeals was extended backwards in time to 1947 after a preliminary examination suggested that there were too few cases in the earlier period studied to permit adequate analysis. ${ }^{2}$ During this period there were a total of 160 such Supreme Court and 1153 appeals court decisions in the area of antitrust policy and 221 Supreme Court and 4454 appeals court labor decisions. Decisions were classified as liberal or conservative following the widely used definition of liberalism most fully described by Goldman (1966).

The first step in analysis was to compute the percentage of liberal decisions made by the Supreme Court in each calendar year for each

\footnotetext{
${ }^{1}$ Labor cases consisted of all cases which involved the resolution of a significant issue included in the "labor relations" topic of the West Key Number System, except those in which an individual as plaintiff raised an equal protection claim against a union or corporation. Suits between unions were also excluded. Most labor cases therefore involved disputes between a union and a company or between employees and their employer. Antitrust cases involved all civil suits in which the plaintiff alleged violation of an antitrust law (primarily the Sherman or Clayton Acts) or in which the defendant raised a counter claim based on the antitrust laws to resist a patent infringement or breach of contract claim. Included in both the labor and antitrust categories were appeals from federal regulatory agencies (e.g., the National Labor Relations Board) and the Federal district courts.

${ }^{2} \mathrm{~A}$ list of the citations of the cases used in analysis may be obtained from the author.
} 
policy area (see appendix) ${ }^{3}$ It was next necessary to determine precisely when and to what extent the decisional trends in Supreme Court labor and antitrust policy-making actually did change. An examination of the data suggests that there were two dramatic changes in the decisional trends of the Supreme Court in each policy area. In labor policy, the Supreme Court became significantly more liberal after 1958 and then took a decisive turn back to the right after 1969. Overall, the Supreme Court announced liberal decisions in $54.3 \%$ of its opinions in the period $1950-1958 ; 79.8 \%$ were liberal in 1959-1969, and 43.0\% were liberal in 1970-77. A difference of proportions test $(Z)$ demonstrates that both of these changes are statistically significant at the .001 level.

More traditional analyses also suggest that significant changes in Supreme Court policy occurred at approximately the same time. For example, Theodore J. St. Antoine states that the Warren Court's "main achievement in the labor field involved a simple but fundamental restructuring of intergovernmental relations. What the court did ... was to nationalize the regulation of labor relations in industries affecting interstate commerce" $(1968$, p. 126). The first definitive statement of this new policy came in the 1959 case of San Diego Building Trades Council v. Garmon, 359 U.S. 236 (St. Antoine, 1968, p. 128; Shapiro, 1964, p. 85). The shift back to a more conservative interpretation of labor policy began in 1970 when the Burger Court announced its decision in Boys Markets Inc. v. Retail Clerk Local 770, 398 U.S. 235, the first of several decisions which expressly overruled two of the Warren Court's prounion decisions and undermined three others (St. Antoine, 1983, p. 166).

In antitrust policy the Supreme Court decisional trends became decidely more liberal after 1956 and then turned back in a conservative direction after 1973. During the 1950-1956 period, $40.6 \%$ of all Supreme Court decisions were liberal. The liberal proportion jumped to $79.5 \%$ for the 1957-1973 period and then fell back to $37.0 \%$ for the 1974-1977 period. Both changes in the proportion of liberal decisions are significant at the .001 level.

Traditional analyses also lead to the conclusion that the Warren and Burger Courts presided over significant shifts in Supreme Court antitrust policy. Kauper writes that "no one could quarrel with the simple assertion that the so-called 'Warren Court' has had a significant, if indeed not extraordinary, impact on the development of antitrust laws" (1968, p. 134). The first of the Warren Court's major antitrust decisions, which marked the first time that the Court has applied the Clayton Act to vertical mergers, occurred in 1957 in the case of United States v. DuPont, 353 U.S. 586 (Shapiro, 1964, pp. 276-77). The DuPont case was quickly followed

${ }^{3}$ Each decision of either the Supreme Court or the courts of appeals which affirmed in part and reversed in part the decision below was scored as half liberal and half conservative. 
by a number of cases, such as the 1958 decision in Northern Pacific Ry. Co. v. United States, 356 U.S. 1, in which the Warren Court declared a wide variety of vertical restraints to be illegal and systematically began to resolve apparent conflicts between patent and antitrust laws in favor of the latter (Kauper, 1968, p. 136). The swing back to the right began with two key decisions in 1974. Markovits argues that the 1974 decision in United States v. Marine Bancorporation, 418 U.S. 602, was the first of several in which the Burger Court "indicated that the test of antitrust legality is the effect of the acts in question on competition rather than their impact on populist democracy or the independence and survival of small businessmen" (1983, p. 180). Also in 1974, the Burger Court announced its decision in United States v. General Dynamics Corporation, 415 U.S. 486, which was the key case on horizontal mergers which repudiated the "Warren Court's apparent conclusion that virtually all horizontal mergers are anticompetitive and hence unlawful" (Markovits, 1983, p. 186).

After determining that Supreme Court policy did, in fact, change significantly in each policy area, decisional trends on the courts of appeals were examined to determine whether they changed in the same direction in the period immediately following the change in Supreme Court policy. The basic unit of analysis was the percentage of liberal decisions announced by the courts of appeals in each policy area for each calendar year (a listing of the results by year is provided in the appendix). The periods used to analyze appeals court decisions are lagged one year to assure that appeals court judges had time to become familiar with changes in Supreme Court policy. The basic test of the hypothesis was to determine whether the proportion of liberal decisions on the courts of appeals changed to a statistically significant degree after the policy change on the Supreme Court. Since it is predicted that the decisional trends of the Supreme Court and the courts of appeals will change in the same direction, a one-tailed difference of proportions test is utilized.

\section{Findings AND Discussions}

The data in table 1 demonstrate that with a one-year time lag, the labor decisional trends on the courts of appeals followed the change in Supreme Court policy as predicted by the hypothesis. After the dramatic increase in Supreme Court liberalism, the percentage of liberal decisions in the courts of appeals increased by $9.1 \%$, a difference that is significant at the .001 level. However, the response by the courts of appeals following the Supreme Court's return to a more conservative orientation is somewhat ambiguous. Although the courts of appeals also became more conservative, the magnitude of the change was much more modest, and the difference failed to reach the .05 level of significance. 
TABLE 1

Proportion of Liberal Decisions in the United States Courts of Appeals during Periods of Changing Supreme Court Policy: Labor Cases

\begin{tabular}{lllll}
\hline PERIOD & \% LIBERAL & $(\mathrm{N})$ & $\mathrm{Z}$ & \\
\hline $1950-59$ & $51.0 \%$ & $(1113)$ & 5.06 & $\mathrm{p}<.001$ \\
$1960-70$ & 60.1 & $(2194)$ & & \\
$1971-77$ & 58.1 & $(1147)$ & 1.11 & $\mathrm{p}=.1$ \\
\hline
\end{tabular}

The data in table 2 also support the hypothesis. Following the Warren Court's adoption of a decidedly more liberal antitrust policy, the output of the courts of appeals also became more liberal. The increase of $8.5 \%$ is significant at the .02 level. The response of the courts of appeals following the turn back to the right by the Supreme Court was also decisive. For the period 1974-1977, the proportion of liberal decisions rendered by the courts of appeals fell $8.6 \%$ from its previous level, a difference that is significant at the .02 level.

TABLE 2

Proportion of Liberal Decisions in the United States Courts of Appeals during Periods of Changing Supreme Court Policy: Antitrust Cases

\begin{tabular}{lllll}
\hline PERIOD & \% LIBERAL & $(\mathrm{N})$ & $\mathrm{Z}$ & \\
\hline $1947-57$ & $34.2 \%$ & $(199)$ & 2.18 & $\mathrm{p}<.02$ \\
$1958-74$ & 42.7 & $(731)$ & & \\
$1975-77$ & 34.1 & $(223)$ & 2.26 & $\mathrm{p}<.02$ \\
\hline
\end{tabular}

Although the findings are not without some ambiguity, they do provide considerable support for the hypothesis. Following each of the four changes in the decisional trends of the Supreme Court, the trends in the courts of appeals moved in the same direction. In three of the cases the differences were statistically significant and in the remaining case the differences were only moderately less than that required for statistical significance.

Although these changes in the decisional trends on the courts of appeals are consistent with the hypothesis of Supreme Court impact, alternative 
explanations are possible. It is well established that there are frequently partisan differences in the voting behavior of appeals court judges (Goldman, 1966, 1975), and in fact, party differences are evident in the data analyzed above. In labor cases, $57.0 \%$ of the votes cast by Democratic judges were liberal compared to $52.0 \%$ for Republican judges-a difference which is significant at the .001 level. In antitrust policy Democrats also cast liberal votes more frequently than their Republican counterparts: $42.7 \%$ compared to $38.5 \%$. These differences are significant at the .01 level. The existence of such partisan differences raises the possibility that the changes in the decisional trends of the courts of appeals may be due to changes in the partisan composition of the lower courts rather than to any Supreme Court influence.

In order to assess this alternative explanation, the votes of individual judges are analyzed in each time period with a control for the party of the appointing president. The data are displayed in tables 3 and 4 . The

TABLE 3

Changes over Time in the Proportion of Liberal Votes Cast by Democratic and Republican Judges on the U.S. Courts of Appeals: LABOR CASES

\begin{tabular}{|c|c|c|c|c|c|}
\hline \multirow[t]{5}{*}{ REPUBLICANS } & PERIOD & q LiBERAL & $(\mathrm{N})$ & $\mathrm{Z}$ & \\
\hline & $1950-59$ & $46.4 \%$ & (1245) & \multirow{4}{*}{$\begin{array}{l}4.82 \\
1.69\end{array}$} & \multirow[b]{2}{*}{$\mathrm{p}<.001$} \\
\hline & $1960-70$ & 54.6 & $(2780)$ & & \\
\hline & & & & & $\mathrm{p}<.05$ \\
\hline & $1971-77$ & 51.9 & $(1529)$ & & \\
\hline \multirow[t]{5}{*}{ Democrats } & Period & q LiBERAL & $(\mathrm{N})$ & $\mathrm{Z}$ & \\
\hline & $1950-59$ & $52.0 \%$ & (1688) & \multirow{3}{*}{4.87} & \multirow{3}{*}{$\mathrm{p}<.001$} \\
\hline & & & & & \\
\hline & $1960-70$ & 59.8 & (2959) & & \\
\hline & 1971.77 & 574 & (1167) & 1.41 & $\mathrm{p}=.08$ \\
\hline
\end{tabular}

changes in the voting patterns of Republican judges are consistent with the hypothesis of Supreme Court impact. For both labor and antitrust policy, the proportion of liberal Republican votes increased to a statistically significant degree after the Warren Court policies became established and then decreased to a statistically significant extent after the 
policy changes adopted by the Burger Court. Democratic judges also followed the trends set by the Supreme Court in both labor and antitrust policy, and the magnitude of the changes was significant at the .01 level in three of the four cases. Although the proportion of the liberal votes cast by Democratic judges is higher than the corresponding figure for Republican judges in each of the three time periods for both policy areas, it is significant that the trends over time for both parties follow the direction of the changes enacted by the Supreme Court.

\section{TABLE 4}

Changes over Time in the Proportion of Liberal Votes Cast by Democratic and Republican Judges on the U.S. Courts of Appeals: Antitrust Cases

\begin{tabular}{lccccc}
\hline REPUblicANS & PERIOD & \% LibERAL & $(\mathrm{N})$ & $\mathrm{Z}$ & \\
\cline { 2 - 6 } & $1947-57$ & $30.1 \%$ & $(186)$ & & \\
$1958-74$ & 41.5 & $(1023)$ & 2.92 & $\mathrm{p}<.01$ \\
$1975-77$ & 34.2 & $(360)$ & 2.43 & $\mathrm{p}<.01$ \\
DEMOCRATS & PERIOD & \% LIBERAL & $(\mathrm{N})$ & $\mathrm{Z}$ & \\
\cline { 2 - 6 } & $1947-57$ & $37.5 \%$ & $(371)$ & & \\
& $1958-74$ & 46.3 & $(961)$ & 2.93 & $\mathrm{p}<.01$ \\
& $1975-77$ & 36.6 & $(262)$ & 2.77 & $\mathrm{p}<.01$ \\
\hline
\end{tabular}

This finding that the voting patterns in both parties followed Supreme Court trends strengthens the support for the proposition that the court has had a significant impact on the decisional trends of the courts of appeals and that the observed changes in the courts of appeals were not due to personnel turnover. However, the use of a party control is only a partial test of turnover effects. Since significant presidential appointment effects have been noted even within parties for federal judges (Carp and Rowland, 1983), the possibility remains that the observed changes were produced by the appointment of judges after the Supreme Court policy shift who were ideologically more in tune with the new policy than were previously appointed judges. Although no independent measure of judges' ideologies was available, this alternative 
was explored by comparing the voting tendencies of holdover judges before and after the changes in Supreme Court policy. ${ }^{4}$ Such an analysis, however, supports the original hypothesis rather than the alternative explanation that new judges were responsible for changes in the decisional trends of the courts of appeals. In labor policy, the proportion of liberal votes cast by holdover judges increased from $49.6 \%$ prior to 1960 to $57.3 \%$ in the middle period and then decreased to $55.9 \%$ after $1970 .{ }^{5}$ In antitrust policy, the proportion of liberal votes cast by holdover judges increased from $37.8 \%$ to $46.8 \%$. The holdovers from the period 1958 to 1974 decreased their support for liberal outcomes from $43.9 \%$ to $35.2 \%$ after $1974 .{ }^{6}$

If the Supreme Court does have a significant effect on the decisions of appeals courts judges, then policy changes adopted by the Court should create new precedents which authoritatively settle some previously unsettled questions and/or which require that previously settled questions now be decided in a different manner. Songer (1982) has argued that a significant proportion of the cases decided by the courts of appeals should be classified as "consensual" cases because the precedents relevant to the decision are so clear and so generally perceived to be binding that all judges, regardless of their ideology, will feel constrained to decide them in the same way. His findings suggested that unanimous affirmances by the courts of appeals are almost always such consensual cases. But if Supreme Court policy change results in new, clear, binding precedents, the cases which would be consensual in one time period might not be consensual in the next period. Therefore, the decisional trends even among these "consensual" cases in the courts of appeals should follow changes in the decisional trends of the Supreme Court if the thesis of the present study is correct. To test this proposition, the decisional trends in the courts of appeals for unanimous affirmances of the district court or regulatory agency decision below were analyzed.

The results support the original hypothesis. For both labor and antitrust cases, the proportion of liberal decisions consistently moves in the

\footnotetext{
${ }^{4}$ A judge was classified as a "holdover" or a "new" judge on the basis of their appointing president rather than their individual date of appointment. Although such a convention, necessitated by the way in which the data were coded, may introduce some inaccuracies (e.g., for labor policy, those few Eisenhower judges appointed in 1960 were classified as holdovers), it does not seem likely that it would significantly affect the results. The only break point between time periods located in the middle of a presidential administration is the division of the first two periods for antitrust policy. Consequently a separate analysis was performed on all Eisenhower appointees, and none were classified as holdover judges. Eisenhower judges increased their proportion of liberal antitrust votes from $30.6 \%$ to $41.3 \%$ after 1957, a change significant at the .05 level.

${ }^{5}$ For the first change, the combined $N=6601, \mathrm{Z}=6.42, \mathrm{P}<.001$. The second change does not reach the .05 level of significance $(\mathrm{Z}=1.05)$.

${ }^{6}$ For the first change, the combined $N=848, Z=2.73, P<.001$. For the second change, the combined $\mathrm{N}=2571, \mathrm{Z}=3.78, \mathrm{P}<.001$.
} 
expected direction. For antitrust policy both changes are statistically significant, while for labor policy only the first change reaches at least the .05 level of significance. ${ }^{7}$

In summary, the analysis reported above suggests that the Supreme Court exercises considerable impact on the general trends in economic policy-making in the United States Courts of Appeals. Even when analysis was confined to judges of a single party, holdover judges, or consensual cases, the trends in the courts of appeals followed the changes in decisional trends of the Supreme Court. The findings reported above of shifts in the decisional trends of the courts of appeals following policy changes in the output of the Supreme Court do not provide definitive proof of causation. It remains possible, for example, that statutory changes or changes in Justice Department prosecution policy were responsible for the shifts on both courts. However, in the absence of any direct evidence to support these alternative explanations, they appear less plausible than the hypothesis of Supreme Court impact.

The major unexplained finding was the failure of the change in the labor decisions of the courts of appeals after 1970 to reach normal standards of statistical significance. The data displayed in table 3 suggest that this failure was due solely to the response of Democratic judges. Although their voting decisions moved in the expected direction, the magnitude of the change was quite modest. A tentative explanation of these results might be found in the suggestion of Carp and Rowland (1983) that the guidelines coming from the Burger Court were more ambiguous than those emanating from the Warren Court. Consequently, judges may have gained relatively more freedom to take their decision-making cues from personal and partisan values after 1970 rather than from guidelines set forth by the High Court.

${ }^{7}$ For antitrust policy, the proportion of liberal decisions increased from $22.3 \%(\mathrm{~N}=121)$ to $30.0 \%(\mathrm{~N}=417)$ in the middle period and then falls to $18.9 \%$. For the first change, $\mathrm{Z}=1.67$, $\mathrm{P}<.05$. For the second change, $\mathrm{Z}=2.27, \mathrm{P}<.02$. For labor policy the proportion of liberal decisions for each period is $66.6 \%(\mathrm{~N}=598), 73.0 \%(\mathrm{~N}=1187)$, and $70.2 \%(\mathrm{~N}=662)$. For the first change, $\mathrm{Z}=2.78, \mathrm{P}<.01$. For the second change, $\mathrm{Z}=1.27, \mathrm{P}=.10$. 


\section{APPENDIX}

\section{Percentage of Liberal Decisions in the Supreme Court and the United States Courts of Appeals By Year and Policy Area}

\begin{tabular}{|c|c|c|c|c|c|c|c|c|}
\hline \multirow[b]{3}{*}{ Year } & \multicolumn{4}{|c|}{ Labor Cases } & \multicolumn{4}{|c|}{ Antitrust Cases } \\
\hline & \multicolumn{2}{|c|}{ Supreme Court } & \multicolumn{2}{|c|}{ Appeals Court } & \multicolumn{2}{|c|}{ Supreme Court } & \multicolumn{2}{|c|}{ Appeals Court } \\
\hline & $q$ Liberal & $\mathbf{N}$ & \% Liberal & $\mathrm{N}$ & \% Liberal & $\mathrm{N}$ & \% Liberal & $N$ \\
\hline 1950 & $29 \%$ & 7 & $33 \%$ & 63 & $33 \%$ & 6 & $36 \%$ & 22 \\
\hline 1951 & 16 & 3 & 40 & 85 & 33 & 6 & 33 & 9 \\
\hline 1952 & 33 & 9 & 58 & 92 & 0 & 2 & 55 & 11 \\
\hline 1953 & 67 & 12 & 52 & 150 & 16 & 6 & 31 & 18 \\
\hline 1954 & 100 & 3 & 55 & 166 & 57 & 7 & 29 & 29 \\
\hline 1955 & 50 & 5 & 57 & 122 & 100 & 3 & 37 & 19 \\
\hline 1956 & 64 & 14 & 48 & 128 & 50 & 2 & 40 & 29 \\
\hline 1957 & 62 & 13 & 47 & 94 & 80 & 5 & 32 & 25 \\
\hline 1958 & 50 & 4 & 59 & 99 & 40 & 5 & 46 & 26 \\
\hline 1959 & 67 & 9 & 48 & 121 & 83 & 6 & 39 & 32 \\
\hline 1960 & 85 & 13 & 51 & 154 & 100 & 4 & 43 & 28 \\
\hline 1961 & 83 & 3 & 56 & 150 & 50 & 4 & 35 & 24 \\
\hline 1962 & 81 & 13 & 61 & 167 & 89 & 9 & 38 & 33 \\
\hline 1963 & 67 & 9 & 60 & 249 & 57 & 7 & 43 & 35 \\
\hline 1964 & 100 & 13 & 57 & 189 & 100 & 8 & 53 & 44 \\
\hline 1965 & 64 & 11 & 58 & 160 & 60 & 5 & 43 & 38 \\
\hline 1966 & 50 & 6 & 60 & 199 & 100 & 6 & 45 & 47 \\
\hline 1967 & 100 & 8 & 63 & 326 & 100 & 10 & 51 & 40 \\
\hline 1968 & 75 & 4 & 57 & 153 & 75 & 8 & 30 & 42 \\
\hline 1969 & 100 & 5 & 63 & 216 & 89 & 9 & 44 & 40 \\
\hline 1970 & 60 & 5 & 66 & 230 & 100 & 1 & 51 & 59 \\
\hline 1971 & 42 & 7 & 56 & 250 & 70 & 5 & 42 & 53 \\
\hline 1972 & 44 & 8 & 64 & 155 & 67 & 6 & 48 & 53 \\
\hline 1973 & 60 & 5 & 59 & 143 & 71 & 7 & 43 & 62 \\
\hline 1974 & 29 & 12 & 62 & 150 & 50 & 8 & 29 & 75 \\
\hline 1975 & 50 & 7 & 57 & 149 & 20 & 5 & 30 & 85 \\
\hline 1976 & 43 & 7 & & & 12 & 4 & & \\
\hline 1977 & 33 & 6 & & & 50 & 6 & & \\
\hline
\end{tabular}

\section{REFERENCES}

Beatty, Jerry K. 1972. State Court Evasion of United States Supreme Court Mandates During the Last Decade of the Warren Court. Valparaiso Law Review, 6:260-85.

Baum, Lawrence. 1977. Judicial Impact as a Form of Policy Implementation. In John A. Gardiner, ed., Public Law and Public Policy. New York: Praeger.

- 1978. Lower Court Responses to Supreme Court Decisions-Reconsidering a Negative Picture. The Justice System Journal, 3:208-19. . 1980. Responses of Federal District Judges to Court of Appeals Policies: An Exploration. Western Political Quarterly, 33:217-24.

Canon, Bradley C. 1973. Reactions of State Supreme Courts to a U.S. Supreme Court Civil Liberties Decision. Law and Society Review, 8:109-34. 
Carp, Robert A., and C. K. Rowland. 1983. Policymaking and Politics in Federal District Courts. Knoxville: University of Tennessee Press.

Goldman, Sheldon. 1966. Voting Behavior on the United States Courts of Appeals, 19611964. American Political Science Review, 60:370-85.

1975. Voting Behavior on the United States Courts of Appeals Revisited. American Political Science Review, 69:491-506.

Johnson, Charles A., and Bradley C. Canon. 1984. Judicial Policies: Implementation and Impact. Washington, DC: Congressional Quarterly Press.

Kauper, Thomas E. 1968. The Warren Court and the Antitrust Laws: Of Economics, Populism, and Cynicism. In Richard H. Sayler, Barry B. Boyer, and Robert E. Gooding, Jr., The Warren Court: A Critical Analysis. New York: Chelsea House.

Markovits, R. S. 1983. The Burger Court, Antitrust, and Economic Analysis. In Vincent Blasi, The Burger Court: The Counter Revolution That Wasn't. New Haven: Yale University Press.

St. Antoine, Theodore J. 1968. Judicial Valour and the Warren Court's Labor Decisions. In The Warren Court: A Critical Analysis. See Kauper, 1968.

. 1983. Individual Rights in the Workplace: The Burger Court and Labor Law. In The Burger Court. See Markovits, 1983.

Shapiro, Martin. 1964. Law and Politics in the Supreme Court. Glencoe, IL: Free Press.

Songer, Donald R. 1982. Consensual and Nonconsensual Decisions in Unanimous Opinions of the United States Courts of Appeals. American Journal of Political Science, 26:22539.

Wasby, Stephen L. 1970. The Impact of the United States Supreme Court: Some Perspectives. Homewood, IL: Dorsey. 